\section{Calcium and 1-Methylcyclopropene Delay Desiccation of Lupinus havardii Cut Racemes}

\author{
G.A. Picchioni ${ }^{1}$ and M. Valenzuela-Vazquez ${ }^{2}$ \\ Department of Agronomy and Horticulture, New Mexico State University, \\ Las Cruces, NM 88003
}

\section{L.W. Murray ${ }^{3}$ \\ Department of Economics and InternationalBusiness, and University Statistics Center, New Mexico State University, Las Cruces, NM 88003}

Additional index words. calcium chloride, senescence, specialty cut flowers, bluebonnet, vase life, plant nutrition

\begin{abstract}
Lupinus havardii Wats. is a promising new specialty cut flower crop, but data on its greenhouse culture and management are limited. Two experiments investigated senescence-delaying activity of preharvest $\mathrm{Ca}$ fertilization and postharvest preconditioning with 1-MCP on $L$. havardii 'Texas Sapphire' cut flower stems (racemes). In the first study, $\mathrm{Ca}\left(\mathrm{as} \mathrm{CaCl}_{2}\right)$ was added to the nutrient culture solution at concentrations of $0,2.5$, 5.0, and $10.0 \mathrm{~mm}$ for 88 days in a greenhouse. Additional $\mathrm{CaCl}_{2}$ supply did not affect the total number of racemes produced per plant, the average number of flowers per raceme, or the retention of individual flowers on cut racemes over a 7-day vase period. However, Ca concentration in cut raceme tissues, ranging from 5.3 to $7.6 \mathrm{mg} \cdot \mathrm{g}^{-1} \mathrm{dry}$ weight, increased linearly with increasing Ca concentration in the nutrient solution, which was accompanied by a linear increase in average fresh weight retention per raceme and individual mature flowers (up to $7 \%$ above controls) during the 7-day vase period. In the second study under similar plant culture and vase conditions, 1-MCP applied at harvest resulted in an average fresh weight retention increase of $9 \%$ above controls during 7 days in the vase. Equivalent levels of desiccation in control racemes (loss in fresh weight retention) were delayed by 1.5 to 3 days in racemes with the highest $\mathrm{Ca}$ concentrations and those that had been preconditioned with 1-MCP. In view of the physiological significance of desiccation in cut flower quality loss, preharvest Ca fertilization and postharvest 1-MCP preconditioning may be useful techniques for delaying senescence and maintaining vase quality of cut L. havardii racemes. Chemical name used: 1-methylcyclopropene (1-MCP)
\end{abstract}

The showy racemes of the winter annual Lupinus havardii Wats. (Big Bend bluebonnet) have excellent commercial potential as a greenhouse-grown specialty cut flower (Davis et al., 1994). The L. havardii raceme is ethylene sensitive and highly perishable (Davis et al., 1994), thus successful commercialization depends strongly on satisfactory postproduction quality and longevity, as is requisite for other new floral crops (Armitage, 1986; Armitage and Wilkins, 1998; Saxtan, 1998). Positive vase life response of cut $L$. havardii racemes to preconditioning treat-

Received for publication 2 July 2001. Accepted for publication 16 July 2001 . This study was supported by the Fred C. Gloeckner Foundation, Harrison, N.Y., the New Mexico Agricultural Experiment Station, Consejo Nacional de Ciencia y Technologia (CONACYT, Mexico), and Instituto Nacional de Investigaciones Forestales, Agricolas, y Pecuarias (INIFAP, Mexico). We thank W.A. Mackay for donation of L. havardii 'Texas Sapphire' seed and for helpful comments during preparation of this manuscript.

${ }^{1}$ Assistant Professor. To whom reprint requests should be addressed. E-mail address: gpicchio@ nmsu.edu

${ }^{2}$ Graduate Research Assistant.

${ }^{3}$ Professor. dency of a plant reproductive structure (Marschner, 1995).

Since the indigenous habitat of L. havardii is confined to calcareous soils of the semiarid southwestern United States (Davis et al., 1994; Soil Conservation Service, 1974, 1985), the species appears to express calcicole-like behavior in a protected environment (Picchioni et al., 2001). Calcium supplementation to its greenhouse culture solution would therefore appear to be a logical strategy to extend vase life of the racemes.

Interest in greenhouse cultivation of $L$. havardii has accrued only recently, thus limited published data exist pertaining to its culture in greenhouse environments, the influence of cultural practices on quality and fresh longevity of its cut racemes, or objective vase life standards. Thus, the objective of this research was to determine the influence of preharvest $\mathrm{Ca}$ application through the nutrient solution and 1-MCP preconditioning on $L$. havardii cut raceme quality changes, particularly on desiccation, which is a major determinant of cut flower senescence (Borochov and Woodson, 1989; Durkin, 1979; Mayak et al., 1974; Paulin et al., 1985).

\section{Materials and Methods}

$\mathrm{CaCl}_{2}$ in nutrient solution study. On 27 Jan. 1998, L. havardii 'Texas Sapphire' seed (previously scarified in concentrated $\mathrm{H}_{2} \mathrm{SO}_{4}$ for $2 \mathrm{~h}$ ) were sown individually into trays with unit cell volume of $170 \mathrm{~mL}$ (\#606; T.O. Plastics, Minneapolis). Cells had been prefilled with Metromix 200 (50\% to 60\% vermiculite, $22 \%$ to $32 \%$ sphagnum moss, and $12 \%$ to $20 \%$ perlite, by volume; Scotts Co., Marysville, Ohio). Trays were placed in a greenhouse with temperature minima of 13 to $18^{\circ} \mathrm{C}$ and maxima of 25 to $35^{\circ} \mathrm{C}$. Maximum midday photosynthetic photon flux $(P P F)$ varied between 550 and $1250 \mu \mathrm{mol} \cdot \mathrm{m}^{-2} \cdot \mathrm{s}^{-1}$ at plant level.

On 21 Feb. (25 d past sowing), 64 seedlings were transplanted into 12 -L plastic pots ( 1 seedling per pot) containing Metromix 200. The experiment was randomized completely with four blocks, each block consisting of four, single-plant pots per $\mathrm{CaCl}_{2}$ treatment. Beginning at transplanting $(21 \mathrm{Feb}$.) and throughout the $\mathrm{CaCl}_{2}$ treatment (described below), pots were hand-irrigated with tap water containing $100 \mathrm{~N}-44 \mathrm{P}-83 \mathrm{~K}$ (in $\mathrm{mg} \cdot \mathrm{L}^{-1}$ ) supplied by Peters $20 \mathrm{~N}-8.8 \mathrm{P}-16.6 \mathrm{~K}$ water soluble fertilizer (J.R. Peters, Allentown, Pa.). Subsequent irrigation for each $\mathrm{CaCl}_{2}$ treatment (initiated and maintained as described below, and added with the fertilizer solution) was provided when an average of $50 \%$ of the total water storage capacity of the medium had been depleted. Water depletion was monitored gravimetrically on four randomly selected pots per treatment (one pot per block), and the irrigation volume (3.4 L per pot) resulted in a leaching fraction of $6 \%$ to $14 \%$. Irrigation interval ranged from 4 to $9 \mathrm{~d}$.

On 8 Apr. ( $1 \mathrm{~d}$ before initiation of $\mathrm{CaCl}_{2}$ treatments), four representative plants (one from each block) were excavated. Roots were 
washed free of growing medium with tap water then rinsed with deionized water. Shoots (combined leaves, petioles, lateral stems, and main stem) and roots were dried at $60{ }^{\circ} \mathrm{C}$ for $10 \mathrm{~d}$, weighed, and saved for dry matter and $\mathrm{Ca}$ analysis as described below.

On 9 Apr., $\mathrm{CaCl}_{2}$ was added to the nutrient solution at concentrations of $0,2.5,5.0$, and $10.0 \mathrm{~mm}$. Reproductive buds had become visible at this time. The electrical conductivity (EC) of the irrigation solution ranged from 0.90 to $2.63 \mathrm{dS} \cdot \mathrm{m}^{-1}$ for 0 and $10 \mathrm{~mm}$ supplemental $\mathrm{CaCl}_{2}$ solution treatments, respectively. Nutrient solution $\mathrm{pH}$ ranged from 6.7 to 6.9. The control solution (tap water and fertilizer without supplemental $\mathrm{CaCl}_{2}$ ) contained $1.2 \mathrm{~mm} \mathrm{Ca}$; hereafter, the four $\mathrm{CaCl}_{2}$ treatment concentrations are referred to as 0 , 2.5, 5.0, and $10.0 \mathrm{~mm}$. The $\mathrm{CaCl}_{2}$ treatments continued for $88 \mathrm{~d}$ (until $6 \mathrm{July}$, or $135 \mathrm{~d}$ past transplanting). At termination (6 July), the mean EC of the saturation extract of a $2-\mathrm{cm}-$ wide $\times 10$-cm-deep core of medium (one pot per treatment per block) was well correlated with $\mathrm{CaCl}_{2}$ concentration in the irrigation solution (medium EC range of 1.66 to 2.65 $\left.\mathrm{dS} \cdot \mathrm{m}^{-1}, r=0.96\right)$. Medium saturation extract $\mathrm{pH}$ ranged from 6.3 to 6.4 .

For 7-d vase evaluations, eight mature racemes (40 to $55 \mathrm{~cm}$ long) were randomly selected from the 16 potted plants per treatment (two racemes per block) on 10 June (62 d past start of treatment, $109 \mathrm{~d}$ past transplanting) between 0800 and $1000 \mathrm{HR}$. The raceme bases were placed in deionized water, and racemes were immediately taken to the laboratory for nondestructive fresh weight and flower retention monitoring during vase conditions. When taken to the laboratory, racemes were recut at the peduncle base, and the proximal $3-\mathrm{cm}$ lengths of rachii of the double-raceme replicates were submerged in individual 250-mL Erlenmeyer flasks (to serve as vases) containing deionized water. The laboratory vase studies $\left(24 \pm 1^{\circ} \mathrm{C}\right)$ were made under continuous cool-white fluorescent lamps with a $P P F$ of $25 \mu \mathrm{mol} \cdot \mathrm{m}^{-2} \cdot \mathrm{s}^{-1}$.

Beginning on the day of cutting (day- 0,10 June), raceme fresh weight and mature flower number were recorded daily for up to $7 \mathrm{~d}$ in the vase. Because of variation in initial raceme fresh weight (average $\mathrm{CV}$ of $23 \%$ within treatments), fresh weight and flower number were expressed as a percentage of the day- 0 replicate value (e.g., fresh weight retention and flower retention). Racemes were dried at $60{ }^{\circ} \mathrm{C}$ for $14 \mathrm{~d}$ and saved for $\mathrm{Ca}$ analysis as described below.

In a supplementary experiment, we determined mature raceme fresh weight distribution during a 7-d vase period. At both the beginning and end of vase observation (as described above), four, 8-raceme replications were divided into two main fractions of 1 ) mature flowers (minus pedicels), and 2) combined rachis + pedicels + apex. The apex was an unexpanded terminal bud on day- 0 which expanded to include 10 to 12 newly opened flowers by the end of vase evaluation.

At the end of the plant culture period (6 July), one randomly selected pot per replicate per treatment was excavated and prepared as described above prior to dry matter and $\mathrm{Ca}$ analysis. Shoot, root, and raceme tissues were ground to pass a 40-mesh screen, and 100 to 200-mg subsamples were subjected to acid block digestion (Parkinson and Allen, 1975). The Ca concentration was determined using a plasma emission spectrometer (JY70+, Instruments J.A., Edison, N.J.). For racemes, only $\mathrm{Ca}$ concentrations on a dry matter basis are presented. Net $\mathrm{Ca}$ accumulation in roots plus shoots during the $\mathrm{CaCl}_{2}$ treatment period (8 Apr. to 6 July) was determined as sum of the products of $\mathrm{Ca}$ concentration by shoot or root dry weight on $6 \mathrm{July}$, minus that obtained on 8 Apr.

Data were subjected to analysis of variance, and sums of squares for $\mathrm{CaCl}_{2}$ irrigation solution concentration main effects were partitioned into single degree of freedom linear and quadratic orthogonal contrasts. Raceme fresh weight and flower retention during vase conditions were analyzed factorially as $\mathrm{CaCl}_{2}$ $\times$ time (four $\mathrm{CaCl}_{2}$ treatments $\times$ seven daily measurements)

1-MCP preconditioning study. In a second experiment, a total of 135 individually potted $L$. havardii plants were grown to obtain harvestable racemes for preconditioning treatment with 1-MCP. Irrigation and fertilization methods (minus the $\mathrm{CaCl}_{2}$ treatments), natural irradiance, vase conditions, and vase evaluation methods were identical to those described for the $\mathrm{CaCl}_{2}$ study, except that vase life estimation was included and defined as the time (days) when $\geq 50 \%$ of mature flowers had abscised or expressed visible desiccation. Greenhouse temperatures were maintained as described in the $\mathrm{CaCl}_{2}$ study, except the maximum temperature ranged from 24 to $27^{\circ} \mathrm{C}$. Seedlings were transplanted and irrigation plus fertilization begun on 4 Dec. 1999 ( 24 d after sowing). On 5 June 2000 (182 d past transplanting), racemes were randomly selected as described for the $\mathrm{CaCl}_{2}$ study.

All racemes (nonpreconditioned controls and those to be preconditioned with 1-MCP) were taken to the laboratory and held under vase conditions described above. EthylBloc $(0.14 \%$ w: w; Floralife, Walterboro, S.C. $)$ was used for 1-MCP generation in an airtight laboratory incubator set at $15{ }^{\circ} \mathrm{C}$ and having a total volume of $0.58 \mathrm{~m}^{3}$. For $1-\mathrm{MCP}$ preconditioning treatment, racemes with freshly cut rachii in water were placed in the incubator equipped with a $10-\mathrm{cm}$ diameter electric fan placed on the bottom shelf to aid gas distribution after 1-MCP volatilization. EthylBloc (145 mg) was added to a beaker resting atop a stirring plate, also positioned on the bottom shelf. The amount of EthylBloc was determined by using commercial recommendations and considering incubator volume, temperature, and treatment duration $(12 \mathrm{~h})$. The incubator was closed, and $2 \mathrm{~mL}$ of $0.44 \%$ (w:v) sodium lauryl sulfate were introduced into the beaker through a tygon tube. The tube was then sealed and the solution stirred for $10 \mathrm{~min}$ for complete volatilization. The fan was left on for $12 \mathrm{~h}$ in darkness, and racemes were taken out of the incubator and exposed to vase conditions.

After recording initial fresh weight and mature flower number (day-0), individual racemes were placed in their flasks containing deionized water and laid out in a completely randomized design (with or without 1-MCP preconditioning) with five replicates. Nondestructive fresh weight and flower count data were recorded daily for $7 \mathrm{~d}$.

\section{Results and Discussion}

$\mathrm{CaCl}_{2}$ study. We did not observe an influence of $\mathrm{CaCl}_{2}$ nutrient solution treatment on total racemes produced per plant or average number of flowers per raceme over the course of $88 \mathrm{~d}$ treatment (data not presented). However, net $\mathrm{Ca}$ uptake per plant during the period of $\mathrm{CaCl}_{2}$ treatment (net accumulation in roots plus shoots) increased with increasing $\mathrm{CaCl}_{2}$ concentration, averaging 797, 1172, 1488, and $1682 \mathrm{mg}$ per plant for the $0,2.5,5.0$, and $10.0 \mathrm{~mm} \mathrm{CaCl}_{2}$ treatments, respectively $(P \leq 0.01)$. Increased $\mathrm{Ca}$ uptake per plant was associated with a parallel increase in raceme $\mathrm{Ca}$ concentration (Table 1).

On the harvest day, total fresh weight per cut raceme was $4.0 \pm 1.3,4.2 \pm 1.0,4.1 \pm 0.5$, and $4.2 \pm 0.8 \mathrm{~g}$ for $0,2.5,5.0$, and $10.0 \mathrm{~mm}$ $\mathrm{CaCl}_{2}$ treatments, respectively. For up to $2 \mathrm{~d}$

Table 1. Main effects of $\mathrm{CaCl}_{2}$ concentration in the nutrient solution and time in vase ( 1 to $7 \mathrm{~d}$ ) on L. havardii 'Texas Sapphire' cut raceme Ca concentration, average fresh weight retention, and average flower retention. ${ }^{z}$

\begin{tabular}{|c|c|c|c|}
\hline $\begin{array}{l}\mathrm{CaCl}_{2} \text { solution } \\
\text { concn }(\mathrm{mm})\end{array}$ & $\begin{array}{c}\text { Raceme Ca concn } \\
\left(\mathrm{mg} \cdot \mathrm{g}^{-1} \text { dry wt }\right)^{\mathrm{y}}\end{array}$ & $\begin{array}{l}\text { Raceme fresh wt } \\
(\% \text { of day- } 0)^{\mathrm{x}}\end{array}$ & $\begin{array}{l}\text { Raceme flower retention } \\
(\% \text { of day }-0)^{x}\end{array}$ \\
\hline 0 (control) & 5.3 & 90.8 & 96.9 \\
\hline 2.5 & 6.1 & 94.1 & 96.5 \\
\hline 5.0 & 7.3 & 95.1 & 94.2 \\
\hline 10.0 & 7.6 & 97.9 & 92.2 \\
\hline \multicolumn{4}{|l|}{ Significance } \\
\hline Days & --- & $* * *$ & $* *$ \\
\hline $\mathrm{CaCl}_{2}(\mathrm{~L})$ & $* * *$ & $* * *$ & NS \\
\hline $\mathrm{CaCl}_{2}(\mathrm{Q})$ & NS & NS & NS \\
\hline Days $\times \mathrm{CaCl}_{2}$ & --- & NS & NS \\
\hline
\end{tabular}

${ }^{\mathrm{z}}$ Each value is the mean of four replicates, each consisting of two racemes.

${ }^{y}$ Single determination at harvest (10 June).

xPooled average across 7 daily measurements during vase conditions.

Ns, ${ }^{* *},{ }^{* * *}$ Nonsignificant or significant at $P \leq 0.01$ or 0.001 , respectively; $\mathrm{CaCl}_{2}$ main effects partitioned into linear $(\mathrm{L})$ or quadratic $(\mathrm{Q})$ orthogonal contrasts. 
in controls and for up to $3 \mathrm{~d}$ in $\mathrm{CaCl}_{2}$-treated plants, raceme fresh weight increased above its harvest (day-0) value (Fig. 1). The early net increase in cut $L$. havardii raceme fresh weight ( 1 to $3 \mathrm{~d}$ ) is a repeatable characteristic (evident in 20 separate experiments; unpublished data), and occurs largely because of water accumulation in the newly expanding flowers of the raceme apex.

Following the early net increase in fresh weight per raceme, the fresh weight decreased by a similar rate for all nutrient solution treatments. The linear contrast for the main effect of vase days on raceme fresh weight (Table 1) was significant for each of the four nutrient solution treatments $(P \leq 0.001)$. After $7 \mathrm{~d}$ in the vase, the relative net loss in fresh weight below the day- 0 value was between $18 \%$ and $29 \%$, depending on treatment. Racemes harvested from $\mathrm{CaCl}_{2}$-supplemented plants held an average of $3.3 \%$ to $7.1 \%$ (138 to $296 \mathrm{mg}$ ) more of their initial fresh weight throughout $7 \mathrm{~d}$ in the vase as compared to the control treatment, and the 7-d average fresh weight retention increased with $\mathrm{CaCl}_{2}$ concentration (Fig. 1 and Table 1). Thus, the linear increase in fresh weight retention of racemes was associated with a linear increase in raceme $\mathrm{Ca}$ concentration.

Results from the raceme fractionation experiment showed that at the beginning of vase conditions, $55.3 \%$ of total raceme fresh weight was present in combined rachis + pedicels + apex, and $44.7 \%$ in mature flowers. At the end of vase conditions, $78.1 \%$ of total raceme fresh weight was present in rachis + pedicels + apex, with only $21.9 \%$ in the mature flowers ( $\mathrm{CV}<8 \%$ for all four measurements). Thus, the major loss in raceme fresh weight after $7 \mathrm{~d}$ (Fig. 1) was due to desiccation of mature flowers $(59.9 \%$ to $67.2 \%$ ) (Table 2). Application of $\mathrm{CaCl}_{2}$ reduced the weight loss of individual flowers as well as remaining inflorescence tissues (rachis + pedicels + apex $)$. In the latter combined raceme fraction, the increase in fresh weight after $7 \mathrm{~d}$ of vase conditions was primarily due to apical expansion.

Retention of flowers per raceme during the 7-d vase period was not affected by the $\mathrm{CaCl}_{2}$ treatments (Table 1; daily observations not presented). By the end of the 7-d vase period, $91 \% \pm 2 \%$ of the 20 to 25 mature flowers remained on the inflorescence. Observation indicated that racemes collected from control plants exhibited a greater tendency to retain visibly wilted flowers as compared to racemes collected from $\mathrm{CaCl}_{2}$-treated plants. This was reflected in the differential fresh weight retention per raceme and mature flowers as discussed above, and indicates that, in this study, fresh weight retention may have been a more important quantitative index of raceme vase quality than was flower retention.

1-MCP preconditioning study. Desiccation was more pronounced with the control racemes than with the 1-MCP-preconditioned racemes, particularly toward the end of the vase period (Fig. 2). Paired $t$ tests of significance indicated that the differences in fresh weight retention were significant at days 4,5 , and $7(P \leq 0.01)$ and at day $6(P \leq 0.05)$. The average fresh weight retention values throughout the vase period were $89.4 \%$ and $98.1 \%$ for control and 1-MCP-preconditioned racemes, respectively. This difference was similar to that observed in the $\mathrm{CaCl}_{2}$ study involving the control and $10 \mathrm{mmCa}$ preharvest irrigation solutions (Table 1). There was no flower abscission on 1-MCP-treated racemes after $7 \mathrm{~d}$ in the vase, whereas control racemes retained an average of only $55 \%$ of their flowers by this time (data not presented).

High $\mathrm{CaCl}_{2}$ and 1-MCP delayed equivalent levels of raceme desiccation by $\approx 1.5$ to

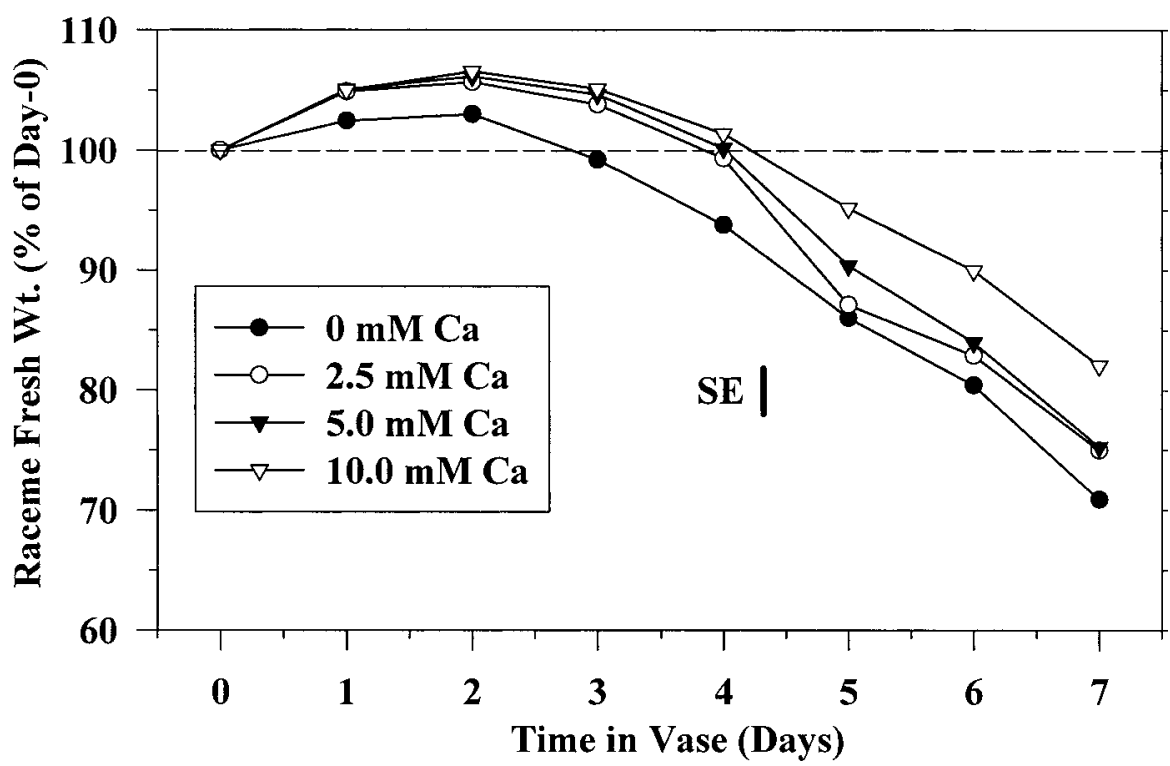

Fig. 1. Daily change in fresh weight of cut $L$. havardii 'Texas Sapphire' racemes during vase life following $\mathrm{CaCl}_{2}$ addition to nutrient solutions at various concentrations. Values are expressed as a percentage of the day- 0 (harvest) weight and are the mean of four replicates, each consisting of two racemes. Net increase in fresh weight is typical for the first few days of vase observation. The sE denotes standard error of a mean.

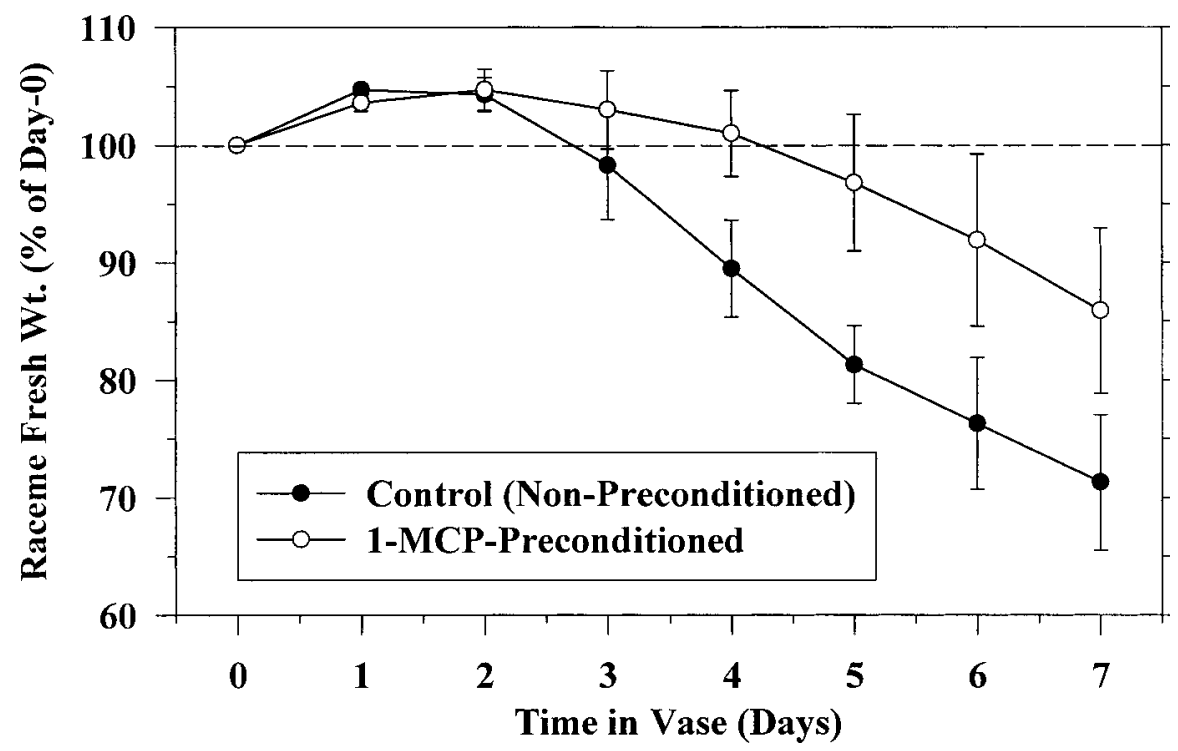

Fig. 2. Fresh weight of cut $L$. havardii 'Texas Sapphire' racemes during vase life following 1-MCP preconditioning at harvest. Net increase in fresh weight is typical for the first few days of vase observation. Each value is the mean \pm SD of five, single-raceme replicates. 
Table 2. Comparison of average fresh weight retention of mature flowers and of the combined rachis, pedicels, and apex of cut L. havardii 'Texas Sapphire' racemes following treatment with various concentrations of $\mathrm{CaCl}_{2}$ in the nutrient solution, and $7 \mathrm{~d}$ in vase conditions. ${ }^{\mathrm{z}}$

\begin{tabular}{|c|c|c|}
\hline \multirow{2}{*}{$\begin{array}{l}\mathrm{CaCl}_{2} \text { solution } \\
\text { concn }(\mathrm{mm})\end{array}$} & \multicolumn{2}{|c|}{ Fresh wt (\% of day- 0$)$} \\
\hline & Mature flowers ${ }^{\mathrm{y}}$ & Rachis + pedicels + apex $^{x}$ \\
\hline 0 (control) & 32.8 & 95.0 \\
\hline 2.5 & 36.6 & 106.0 \\
\hline 5.0 & 36.8 & 106.4 \\
\hline 10.0 & 40.1 & 116.0 \\
\hline \multicolumn{3}{|l|}{ Significance } \\
\hline $\mathrm{CaCl}_{2}(\mathrm{~L})$ & $*$ & $*$ \\
\hline $\mathrm{CaCl}_{2}(\mathrm{Q})$ & NS & NS \\
\hline
\end{tabular}

${ }^{\mathrm{z}}$ Each value is the mean of four replicates, each consisting of two racemes. ${ }^{y}$ Defined as fully expanded flowers at the time of harvest.

${ }^{x}$ Defined as all inflorescence tissues subtending fully expanded flowers (rachis+pedicels) and apical inflorescence tissues (apex) present at time of harvest which had expanded during vase conditions.

Ns, *Nonsignificant or significant at $P \leq 0.05 ; \mathrm{CaCl}_{2}$ main effects partitioned into linear (L) or quadratic (Q) orthogonal contrasts.

fore, such a deferral of water loss is of practical importance for quality maintenance of the cut racemes.

In cut carnation, ethylene accelerates loss of water from the petals and reduces water uptake by the cut stem (Lieberman et al., 1964; Mayak et al., 1977). Thus, 1-MCP, an inhibitor of ethylene action (Sisler et al., 1996), delayed desiccation of the ethylenesensitive $L$. havardii raceme in our study (Fig. 2). In ripening apple fruit (a widelystudied ethylene-forming plant organ), elevated tissue $\mathrm{Ca}$ concentration delays the climacteric peak in ethylene synthesis (Lieberman and Wang, 1982). The similarity in 1-MCP and high $\mathrm{CaCl}_{2}$ in delaying desiccation of cut $L$. havardii racemes may indicate that both 1-MCP-treated and high-Ca racemes were partially protected from the deleterious effects of ethylene.

Results suggest that both preharvest $\mathrm{Ca}$ application and postharvest 1-MCP preconditioning delay desiccation and thus extend postproduction life of cut L. havardii racemes. Direct comparisons of the effectiveness of $\mathrm{Ca}$ fertilization and 1-MCP treatment cannot be made here, since both studies were conducted at different times and with different crops of racemes. There was similar improvement in fresh weight retention by $1-\mathrm{MCP}$ and raceme Ca "enrichment" (up to $7.6 \mathrm{mg} \cdot \mathrm{g}^{-1}$ dry weight) above that of their counterpart control treatments. However, 1-MCP appears to offer greater potential for improving the retention of fresh flowers, as recently reported by Sankhla et al., (1999), and as indicated in our present study.

\section{Literature Cited}

Armitage, A.M. 1986. Evaluation of new floricultural crops: A systems approach. HortScience 21:9-11.

Armitage, A.M. and H. Wilkins. 1998. The new world order in ornamental plants. GrowerTalks 62(1):60-66.

Borochov, A. and W.R. Woodson. 1989. Physiology and biochemistry of flower petal senescence. Hort. Rev. 11:15-43.

Davis, T.D., S.W. George, W.A. Mackay, and J.M Parsons. 1994. Development of Texas bluebonnets into floricultural crops. HortScience 29:1110, 1211.

Davis, T.D., W.A. Mackay, and N. Sankhla. 1995 Postharvest characteristics of cut inflorescences of Lupinus havardii. HortTechnology 5:247249.

Durkin, J.D. 1979. Some characteristics of water flow through isolated rose stem segments. J. Amer. Soc. Hort. Sci. 104:777-783.

Ferguson, I.B. 1984. Calcium in plant senescence and fruit ripening. Plant, Cell, Environ. 7:477-489.

Harbaugh, B.K. and S.S. Woltz. 1989. Fertilization practice and foliar-bract calcium sprays reduce incidence of marginal bract necrosis of poinsettia. HortScience 24:465-468.

Huett, D.O. 1994. Production and quality of Sim carnations grown hydroponically in rockwool substrate with nutrient solutions containing different levels of calcium, potassium, and ammonium-nitrogen. Austral. J. Expt. Agr. 34:691-697.

Lawton, K.A., G.L. McDaniel, and E.T. Graham. 1989. Nitrogen source and calcium supplement affect stem strength of poinsettia. HortScience 24:463-465.

Lieberman, M., S. Asen, and L.W. Mapson. 1964. Ethylene oxide an antagonist of ethylene in metabolism. Nature 204:756-758.
Lieberman, M. and S.Y. Wang. 1982. Influence of calcium and magnesium on ethylene production by apple tissue slices. Plant Physiol. 69:11501155 .

Mackay, W.A., D. Sankhla, T.D. Davis, and N. Sankhla. 1999. Studies on postharvest performance of cut racemes of Big Bend bluebonnet. HortScience 34:503. (Abstr.)

Marschner, H. 1995. Mineral nutrition of higher plants, p. 298. Academic, New York.

Mayak, S., H. Halevy, S. Sagie, A. Bar-Yoseph, and B. Bravdo. 1974. The water balance of cut rose flowers. Physiol. Plant. 31:15-22.

Mayak, S., Y. Vaadia, and D.R. Dilley. 1977. Regulation of senescence in carnation (Dianthus caryophyllus) by ethylene. Plant Physiol. 59:591-593.

Mikesell, J.E. 1992. Influence of calcium on vegetative and reproductive development of Pelargonium. J. Plant Nutr. 15:1323-1341.

Parkinson, J.A. and S.E. Allen. 1975. A wet oxidation technique suitable for the determination of nitrogen and other mineral nutrients in biological materials. Commun. Soil. Sci. Plant. Anal. $6: 1-11$.

Paulin, A., F. Kerhardy, and B. Maestri. 1985. Effect of drought and prolonged refrigeration on senescence in cut carnation (Dianthus caryophyllus). Physiol. Plant. 64:535-540.

Picchioni, G.A., M. Valenzuela-Vazquez, and S. Armenta-Sanchez. 2001. Calcium-activated root growth and mineral nutrient accumulation of Lupinus havardii: Ecophysiological and horticultural significance. J. Amer. Soc. Hort. Sci. 126:631-637.

Sankhla, N., W.A. Mackay, and T.D. Davis. 1999. Effect of EthylBloc on postharvest performance and ethylene production of cut racemes of Big Bend bluebonnet. Proc. Plant Growth Reg. Soc. Amer. 26:190-192.

Saxton, J. 1998. The wheres and whys of floral purchases. Green Profit 2(4):24-25.

Serek, M., E.C. Sisler, and M.S. Reid. 1995. Effects of 1-MCP on the vase life and ethylene response of cut flowers. Plant Growth Regulat. 16:93-97.

Sisler, E.C., E. Dupille, and M. Serek. 1996. Effect of 1-methylcyclopropene and methylcyclopropane on ethylene binding and ethylene action on cut carnations. Plant Growth Regulat. 18:7986.

Soil Conservation Service. 1974. Soil survey of Terrell County, Texas. Soil Cons. Serv. and Texas Agr. Expt. Sta.

Soil Conservation Service. 1985. Soil survey of Big Bend National Park-Part of Brewster County, Texas. Soil Cons. Serv. and Texas Agr. Expt. Sta.

Starkey, K.R. and A.R. Pedersen. 1997. Increased levels of calcium in the nutrient solution improve the postharvest life of potted roses. J. Amer. Soc. Hort. Sci. 122:863-868.

Torre, S., A. Borochov, and A.H. Halevy. 1999. Calcium regulation of senescence in rose petals. Physiol. Plant. 107:214-219. 